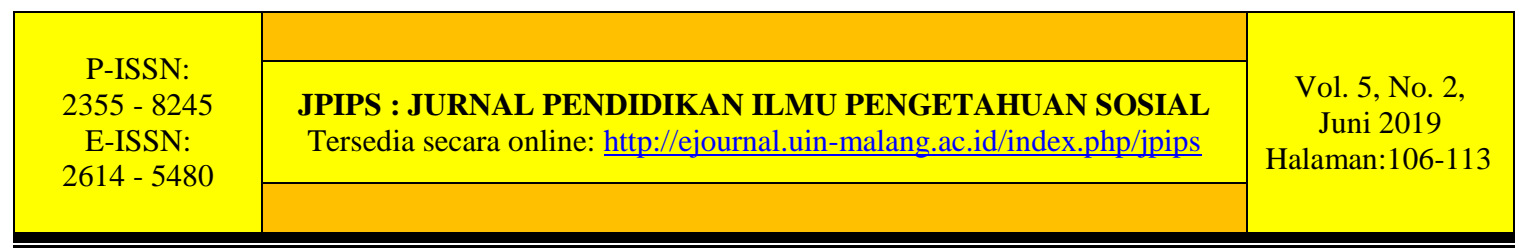

\title{
PENGARUH MODEL PEMBELAJARAN INKUIRI TERBIMBING TERHADAP MOTIVASI DAN HASIL BELAJAR SISWA
}

\author{
Riza Kurnia Silfi, Choiru Umatin \\ IAIN Tulungagung, IAIN Kediri \\ jaladry96@gmail.com, choiruummatin@gmail.com
}

\begin{abstract}
Abstrak:
Setting model pembelajaran inkuiri memacu siswa untuk selalu bertanya dan berdiskusi yang memungkinkan siswa berlatih berkomunikasi dengan orang lain sehingga meningkatkan keterampilan sosialnya. Riset ini bertujuan untuk mengetahui pengaruh model pembelajaran inkuiri terbimbing terhadap motivasi dan hasil belajar IPS siswa kelas VII SMPN 01 Sumbergempol Tulungagung. Metode dalam riset ini menggunakan metode kuantitatif. Sampel dalam riset ini berjumlah 66 siswa dengan kelas eksperimen 34 dan kelas kontrol 32 siswa. Analisis data menggunakan uji T dan Mannova. Hasil riset ini menunjukkan:1) adanya pengaruh model pembelajaran inkuiri terbimbing terhadap motivasi belajar siswa. Uji hipotesis diperoleh $t$ hitung (13.673) $>\mathrm{t}$ tabel (1.995) maka terima H_0. 2) Adanya pengaruh model pembelajaran inkuiri terbimbing terhadap hasil belajar siswa. Uji hipotesis diperoleh $t$ hitung $(15.433)>t$ tabel (1.995) maka terima H_0. 3) Adanya pengaruh yang signifikan model pembelajaran inkuiri terbimbing terhadap motivasi dan hasil belajar siswa. Berdasarkan hasil uji manova, menunjukkan bahwa nilai signifikansi adalah 0,000. Nilai tersebut dibawah nilai probabilitas yaitu $0,05(0,000<0,05)$. Diketahui dalam pengujian ini menunjukkan H_a diterima kemudian H_0 ditolak. Artinya ada pengaruh yang signifikan antara penggunaan model pembelajaran inkuiri terbimbing terhadap motivasi dan hasil belajar. Penelitian ini berkontribusi dalam menciptakan pembelajaran yang aktif, kreatif dan efektif sehingga motivasi dan hasil belajar siswa bisa meningkat.
\end{abstract}

\section{Kata Kunci: Inkuiri, Motivasi dan Hasil Belajar IPS.}

\begin{abstract}
:
Setting the inquiry learning model encourages students to always ask questions and discuss allowing students to practice communicating with others so as to improve their social skills. This research aims to determine the effect of guided inquiry learning model on social studies motivation and learning outcomes of class VII students of SMP 01 Sumbergempol Tulungagung. The method in this research uses quantitative methods. The sample in this research amounted to 66 students with an experimental class of 34 and a control class of 32 students. Data analysis using T and Mannova tests. The results of this research show: 1) the influence of a guided inquiry learning model on student learning motivation. Hypothesis testing obtained t count $(13,673)>t$ table (1995) then accept H_0. 2) The influence of guided inquiry learning model on student learning outcomes. Hypothesis testing obtained $t$ count $(15,433)>t$ table (1995) then accept H_O. 3) There is a significant influence of guided inquiry learning model on student motivation and learning outcomes. Based on the results of the manova test, the significance value is 0,000. This value is below the probability value of $0.05(0,000$
\end{abstract}


$<0,05)$. It is known that this test shows $H \_a$ received then $H \_O$ is rejected. This means that there is a significant influence between the use of guided inquiry learning models on motivation and learning outcomes. This research contributes to creating active, creative and effective learning so that students' motivation and learning outcomes can increase.

\section{Keywords: Inquiry, Motivation and learn Results.}

\section{PENDAHULAN}

Pembelajaran yang baik merupakan pembelajaran yang menyenangkan, kreatif, efektif, dan inovatif dengan pendekatan, strategi, dan metode yang prosesnya membutuhkan partisipasi aktif siswa. Siswa akan menjadi pasif apabila pembelajaran konvensional masih terpusat atau didominasi guru (teacher centered). Hal ini dianggap tidak efektif dalam membentuk pembelajaran yang menarik dan bermakna, karena tidak bisa memberikan peluang kepada siswa untuk berkembang secara mandiri (Sapriya, 2009:7). Banyak usaha yang dilakukan guru untuk keberhasilan kegiatan belajar mengajar, salah satunya adalah memilih dan memahami metode yang tepat (Djamarah, 2010: 72).

Guru seringkali melakukan pembelajaran yang kurang memperhatikan pendekatan, strategi dan metode yang tepat disajikan dalam satu materi/satu pokok bahasan. Guru harus selalu memahami fungsi-fungsi mengajar agar dapat menjalankan tugas mengajar dengan sebaik-baiknya. Tugas guru akan terlaksana dengan baik apabila diimbangi dengan cara mengajar yang tepat salah satunya dengan pemilihan modelmodel pembelajaran yang sesuai.

Model mengajar merupakan suatu pemahaman yang harus dikuasai seorang guru tentang bagaimana cara mengajar dan teknik penyajian bahan pelajaran kepada peserta didik baik secara individual maupun kelompok di dalam kelas sehingga pelajaran mudah diserap, di pahami, dan dianalisis serta di manfaatkan peserta didik dengan baik. Banyak model yang dapat dipilih guru sebagai alternatif dalam mengajarkan IPS akan tetapi belum tentu suatu model dapat digunakan dan cocok digunakan pada semua materi / pokok bahasan dalam pelajaran tersebut. Oleh karena itu guru harus pintar memilih model yang tepat dan dipandang lebih efektif daripada model-model yang lain.

Model inkuiri terbimbing merupakan model yang untuk menggambarkan dengan jelas tentang hal-hal yang berhubungan dengan praktik, proses terjadinya sesuatu, dan mengetahui kebenaran sesuatu. Model inkuiri terbimbing adalah suatu aktivitas dalam menemukan dan menyelidiki masalah-masalah, menyusun hipotesa, melakukan eksperimen, pengumpulan data, dan menarik kesimpulan dari hasil pemecahan masalah (problem solving). Penggunaan model ini bertujuan untuk membantu siswa dalam mengembangkan disiplin intelektual dan keterampilan yang dibutuhkan serta mengajak siswa untuk aktif dalam memecahkan masalah sehingga siswa terdidik mandiri dalam menyelesaikan persoalannya. Model ini mampu membuat siswa berfikir kreatif inovatif dalam menemukan bukti kebenaran dari teori yang sedang di pelajarinya.

Model pembelajaran inkuiri terbimbing merupakan model pembelajaran yang berorientasi pada beberapa aktivitas yang bersifat ilmiah. Model ini menuntut siswa menyampaikan ide-ide mereka sebelum topik-topik tersebut mereka pelajari, siswa menyelediki suatu gejala atau fenomena yang mereka anggap ganjil, siswa mendeskripsikan suatu fakta-fakta dan membandingkan secara saintifik serta 
menanyakan situasi yang mendukung pembelajaran seperti perlengkapan sains dan teknologi (Irmawati, 2003: 90).

Dalam pembelajaran ini guru bertindak selaku organisator dan fasilitator, guru tidak memberitahukan konsep-konsep tetapi membimbing siswa menemukan konsepkonsep tersebut dengan melalui kegiatan belajar. Sehingga konsep yang didapat berdasarkan kegiatan dan pengalaman belajar tersebut akan selalu diingat siswa dalam waktu yang lama. Tahapan-tahapan model pembelajaran inkuiri terbimbing dapat mengakomodasi kegiatan-kegiatan yang mengarah pada peningkatan keterampilan berpikir kritis siswa (Puspita \& Jatmiko, 2013: 122-123).

Motivasi merupakan suatu perubahan energi dalam pribadi seseorang yang ditandai dengan timbulnya afektif (perasaan) dan reaksi untuk mencapai tujuan. Motivasi menurut Sumadi Suryabrata adalah keadaan yang terdapat dalam diri seseorang yang mendorongnya untuk melakukan aktivitas tertentu guna pencapaian suatu tujuan. Sementara itu Gates dan kawan-kawan mengemukakan bahwa motivasi adalah suatu kondisi fisiologis dan psikologis yang terdapat dalam diri seseorang yang mengatur tindakannya dengan cara tertentu (Djamarah, 2002: 114). Jadi motivasi adalah kondisi seseorang yang terdorong untuk melakukan aktivitas guna mencapai tujuan.

Hasil belajar memiliki arti memperoleh pengetahuan atau menguasai pengetahuan melalui pengalaman, mengingat, menguasai pengalaman, dan mendapatkan informasi atau menemukan. Dengan demikian, belajar diartikan sebagai dasar adanya aktivitas atau kegiatan untuk menguasai sesuatu, untuk mendapatkan hasil belajar yang maksimal. Hasil belajar dapat dideskripsikan dengan pemahaman dua kata yang membentuknya, yaitu "hasil" dan“belajar"( Baharuddin \& Wahyuni, 2012:13).

Hasil penelitian yang dilakukan oleh Novita, et al., (2013) pada materi sistem koloid, menyatakan bahwa pembelajaran dengan model penemuan terbimbing dapat meningkatkan motivasi belajar dan penguasaan konsep siswa. Hal ini didukung dengan penelitian yang dilakukan oleh Rahmawati (2014) bahwa pembelajaran inkuiri terbimbing efektif dalam meningkatkan motivasi belajar siswa dan keterampilan proses sains siswa. Selain itu hasil penelitian yang dilakukan oleh Reliyana, et al.,.(2014) pada materi hukum-hukum dasar kimia, menunjukkan bahwa model inkuiri terbimbing efektif dalam meningkatkan motivasi belajar dan penguasaan konsep hukum-hukum dasar kimia siswa. Dengan demikian, diharapkan model pembelajaran inkuiri terbimbing berpengaruh signifikan terhadap motivasi dan hasil belajar siswa materi kelangkaan dan kebutuhan manusia kelas VII SMPN 1 Sumbergempol Tulungagung.

\section{METODE}

Penelitian ini menggunakan pendekatan kuantitatif dengan variabel bebas atau independen yaitu model pembelajaran Inkuiri Terbimbing dan variabel terikat atau dependen yaitu motivasi dan hasil belajar. Penelitian ini menggunakan desain quasi experimental (eksperimen semu) peneliti tidak bisa secara maksimal mengontrol variabel-variabel luar yang berpengaruh dalam pelaksanaan penelitian. Penelitian ini menggunakan jenis nonequivalent control group design yaitu dengan menggunakan" pre-test posttest control group design". Desain ini membutuhkan perlakukan yang mana kedua kelompok diberi tes awal atau pretest untuk mengukur kondisi/kemampuan awal. Selanjutnya pada kelompok eksperimen diberi tes akhir (post_test) setelah dilakukan perlakuan. Pada kelas eksperimen akan dilakukan penerapan model pembelajaran Inkuiri Terbimbing (Guidded Inquiry) dan kelompok kontrol tidak diberi perlakuan (Sugiono, 2007:10). 
Variabel bebas dalam penelitian ini adalah Model Pembelajaran Inkuiri Terbimbing, yang selanjutnya disebut dengan variabel X. Variabel terikatnya adalah Y1: motivasi belajar dan Y2: hasil belajar. Dalam penelitian ini, populasinya adalah keseluruhan peserta didik kelas VII SMPN 1 Sumbergempol Tulungagung dengan jumlah 350 siswa. Teknik pengambilan sampel dalam penelitian ini menggunakan teknik nonprobability sampling dengan purposive sampling yaitu teknik penentuan sampel dengan pertimbangan tertentu (Sugiono, 2007:11). Instrumen pengumpulan data dalam penelitian ini meliputi angket, tes dan dokumentasi.

Dalam penelitian ini, angket digunakan untuk pengumpulan data mengenai motivasi belajar siswa.

Tabel 1.Teknik Penskoran Angket

\begin{tabular}{ccc}
\hline \multirow{2}{*}{ Respon } & \multicolumn{2}{c}{ Nilai } \\
\cline { 2 - 3 } SS & Positif & Negatif \\
S & 5 & 1 \\
KS & 4 & 2 \\
TS & 3 & 3 \\
STS & 2 & 4 \\
\hline
\end{tabular}

Sumber: (Sugiyono, 2007: 135)

Tabel 2. Prosentase Nilai

\begin{tabular}{cl}
\hline Jawaban & \multicolumn{1}{c}{ Keterangan } \\
\hline $0 \%-24,99 \%$ & Sangat (Tidak Setuju, Buruk Atau Kurrang Sekali) \\
$25-49,99 \%$ & Tidak setuju atau Kurang \\
& Baik \\
$50 \%-74,99 \%$ & Cukup atau Netral \\
$75 \%-99,99 \%$ & Setuju, Baik atau Suka \\
$100 \%-125 \%$ & Sangat (Setuju, Baik, Suka) \\
\hline
\end{tabular}

Sumber: Data Diolah

Selanjutnya peneliti memberikan tes kepada siswa setelah diberikan perlakuan. Instrumen tes diberikan peneliti ketika kelas sudah diberi perlakuan. Sasaran kelas yang diberikan tes adalah kelas eksperimen maupun kelas kontrol

Tabel 3. Kategori Ketuntasan Belajar Kognitif Siswa

\begin{tabular}{cll}
\hline No & Rentang Nilai $(\%)$ & Kategori \\
\hline 1. & $\geq 80 \%$ & Sangat Tinggi \\
2. & $60-79 \%$ & Tinggi \\
3. & $40-59 \%$ & Sedang \\
4. & $20-39 \%$ & Rendah \\
5. & $<20 \%$ & Sangat rendah \\
\hline
\end{tabular}

Sumber: (Trianto, 2011: 56)

Pada penelitian ini, peneliti menggunakan analisis data yaitu uji T-Test dan Analysis Varian Multivarians (MANOVA), Uji T-Test adalah teknik statistik yang dipergunakan untuk menguji signifikansi perbedaan dua buah mean yang berasal dari dua buah distribusi (Sugiono, 2007:13). 
HASIL DAN PEMBAHASAN

Hasil

Tabel 4. Hasil output SPSS UJI $t$ - Test Nilai Motivasi Belajar Independent Samples Test

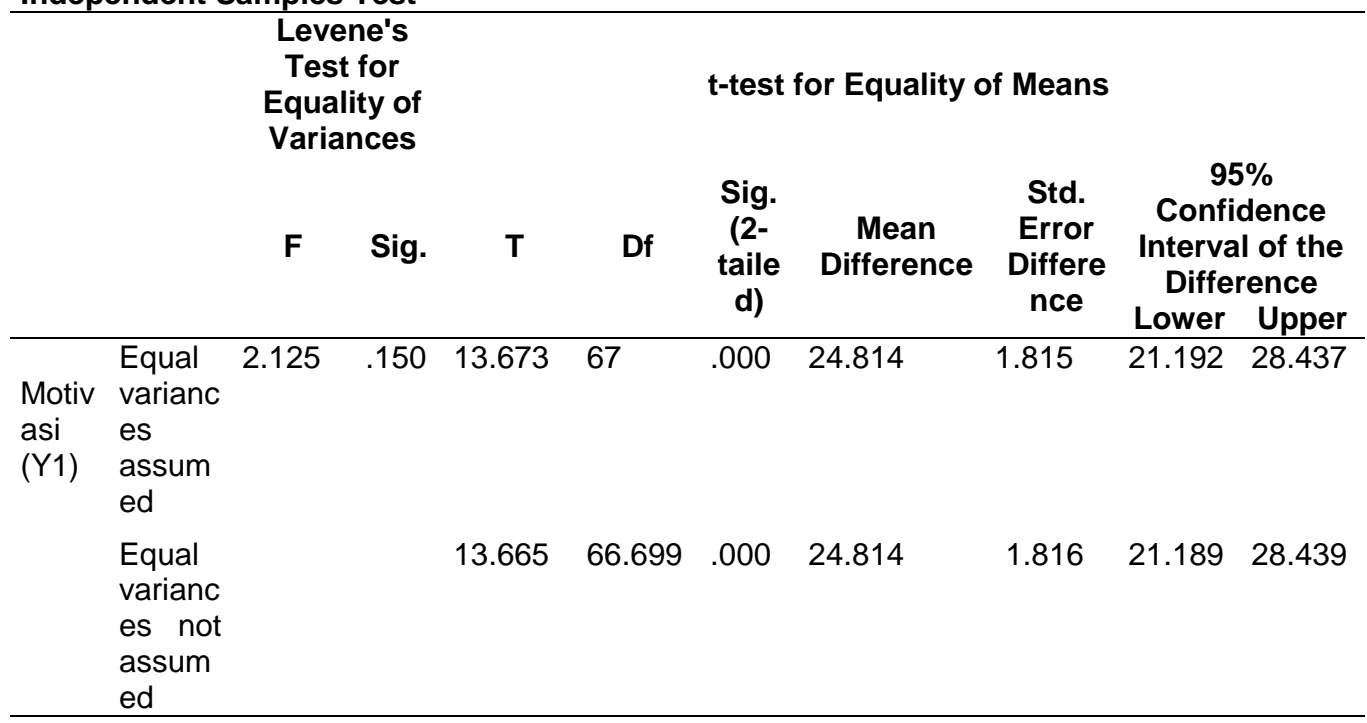

Berdasarkan Tabel 4 diperoleh nilai sig. 0,150 >0,05 dan ditulis t hitung (13.673) $>\mathrm{t}$ tabel 1.995 maka terima $H_{0}$

Tabel 5. Hasil output SPSS UJI t- Test Nilai Hasil Belajar

Independent Samples Test

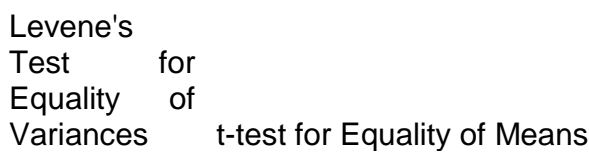

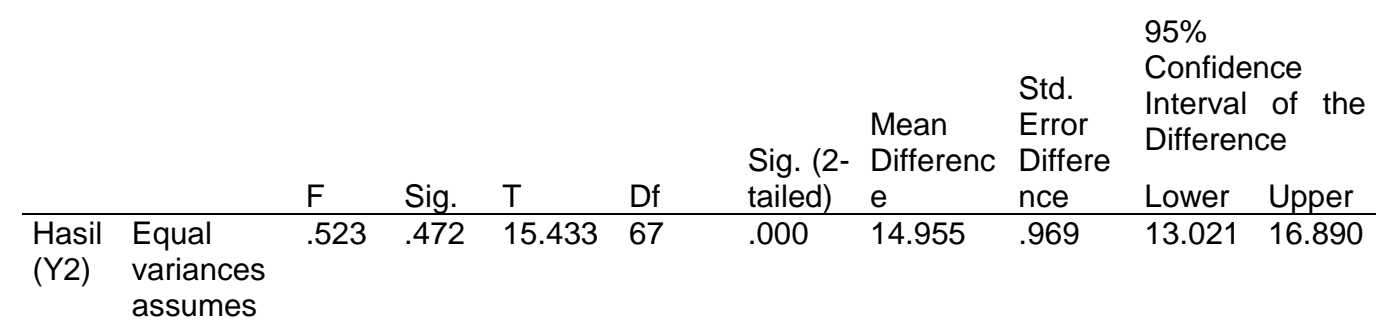

Equal

variances

not

assumes

Berdasarkan Tabel 5 hipotesis $t$ - test melalui program SPSS 18.0 dengan menggunakan independent sample test pengujian uji hipotesis $t$ - test diperoleh besaran nilai sig. 0,472 >0,05 dan dengan $t$ hitung $(15.433)>\mathrm{t}$ tabel $(1,995)$ tabel $(4.10)$.

\section{Pembahasan}

Motivasi sangat erat hubungannya dengan kebutuhan. Sebab memang motivasi muncul karena kebutuhan. Kebutuhan ini yang menimbulkan keadaan ketidak 
seimbangan (ketidakpuasan), yaitu ketegangan-ketegangan, dan ketegangan itu akan hilang manakala kebutuhan itu telah terpenuhi (Sanjaya, 2009: 174). Keaktifan dan partisipasi dalam diskusi untuk memecahkan masalah melalui pengamatan akan menumbuhkan motivasi belajar yang tinggi pada siswa dan pada akhirnya akan berpengaruh terhadap hasil belajar (Purwanto, 2012).

Hasil uji normalitas diperoleh bahwa nilai motivasi belajar siswa kelas eksperimen dan kontrol adalah normal dan motivasi siswa kelas eksperimen dan kontrol adalah normal sedangkan berdasarkan uji homogenitas dengan bantuan SPSS 18.0 diperoleh bahwa varian data hasil belajar kelas eksperimen dan kontrol adalah homogen. Dengan terpenuhinya uji prasyarat yaitu uji normalitas dan uji homogenitas, maka langkah selanjutnya yaitu pengujian hipotesis $t$ - test melalui program SPSS 18.0. berdasarkan dari analisis data menunjukkan bahwa ada pengaruh model pembelajaran inkuiri terbimbing terhadap motivasi belajar siswa. Hal ini ditunjukkan oleh nilai sig. $0,150>0,05$ dan ditulis t hitung (13.673) $>\mathrm{t}$ tabel 1.995 maka terima $H_{0}$ tabel.

Kesimpulan dari uji hipotesis adalah $H_{0}$ ditolak dan $H_{a}$ di terima, artinya ada pengaruh model pembelajaran inkuiri terbimbing terhadap motivasi belajar siswa materi kelangkaan dan kebutuhan manusia kelas VII SMPN 1 Sumbergempol Tulungagung. Analisis data membuktikan bahwa pembelajaran yang dilakukan guru mempengaruhi motivasi belajar karena peserta didik merasa bahwa materi tersebut dapat memenuhi kebutuhannya, maka ia akan termotivasi untuk mempelajarinya (Trisnawati 2008). Adanya pengaruh model pembelajaran inkuiri terbimbing dikarenakan lebih baik penerapannya yang terpusat pada siswa daripada siswa hanya terpusat pada guru saja.

Melalui pembelajaran inkuiri terbimbing, siswa menjadi termotivasi untuk belajar dalam dirinya, peningkatan pemahaman terhadap materi kelangkaan dan kebutuhan manusia dan siswa juga mampu menyelesaikan suatu permasalahan materi ekonomi. Motivasi tersebut mencakup beberapa aspek, diantaranya minat dan perhatian selama proses pembelajaran berlangsung, semangat dan partisipasi siswa dalam mengerjakan tugas-tugasnya, dan rasa tanggung jawab siswa yang tinggi dalam menyelesaikan persoalan.

Model pembelajaran inkuiri terbimbing tidak hanya berpengaruh terhadap motivasi belajar saja tapi juga hasil belajar. Ukuran yang digunakan seorang guru untuk mengetahui tingkat penguasaan siswa terhadap bahan yang diajarkan seringkali menggunakan hasil belajar yang merupakan bagian dari penilaian kognitif siswa. Untuk mengaktualisasikan hasil belajar siswa dibutuhkan serangkaian pengukuran menggunakan alat evaluasi yang baik dan memenuhi syarat (Baharuddin \& Wahyuni, E.N. 2012: 13).

Sudjana (2002:5) mendefinisikan hasil belajar siswa pada hakikatnya yaitu proses perubahan tingkah laku siswa yang merupakan hasil belajar dalam cakupan makna yang lebih luas meliputi bidang kognitif, afektif, dan psikomotorik. Ketiga ranah tersebut dijadikan sebagai objek penilaian hasil belajar. Dari ketiga ranah tersebut, para guru disekolah banyak menggunakan acuan ranah kognitif untuk mengukur tingkat kemampuan para siswa dalam memahami dan menguasai materi atau isi bahan pelajaran (Sudjana, 2011: 23).

Hasil analisis uji normalitas menunjukkan bahwa nilai hasil belajar siswa kelas eksperimen berdistribusi normal dan nilai hasil belajar siswa kelas kontrol juga berdistribusi normal (Tabel 5). Hasil uji homogenitas dengan bantuan SPSS 18.0 menghasilkan varian data hasil belajar kelas eksperimen dan kelas kontrol adalah homogen. Uji normalitas dan uji homogenitas telah memenuhi uji prasyarat, maka 
langkah selanjutnya dilakukan pengujian normalitas dan homogenitas, maka langkah selanjutnya yaitu penguji hipotesis $t$ - test melalui program SPSS 18.0 dengan menggunakan independent sample test. Pengujian hipotesis $t$ - test diperoleh besaran nilai sig. 0,472 >0,05 dan dengan $t$ hitung $(15.433)>t$ tabel $(1,995)$.

Hasil dari uji hipotesis adalah $H_{0}$ ditolak $H_{a}$ diterima, artinya terdapat pengaruh model pembelajaran inkuiri terbimbing terhadap hasil belajar siswa materi kelangkaan dan kebutuhan manusia kelas VII SMPN 1 Sumbergempol Tulungagung. Adanya pengaruh karena terdapat perbedaan nilai hasil belajar siswa. Siswa yang belajar dengan menggunakan model pembelajaran inkuiri terbimbing memiliki nilai rata-rata yang lebih besar dibandingkan dengan pembelajaran konvensional yaitu 91.51 dan 76.56.

Hal ini diperkuat dengan hasil penelitian Deta (2013) bahwa rata-rata prestasi belajar kognitif siswa dengan metode inkuiri terbimbing lebih baik daripada siswa dengan metode proyek sekalipun (Deta, U. A., Suparmi \& Widha, S., 2013: 28-34). Lundgren (1991) dalam Mc Daniel \& Green (2012: 3) mengatakan bahwa penerapan pembelajaran berbasis inkuiri terbimbing memiliki beberapa keuntungan, salah satunya adalah meningkatkan prestasi akademik siswa (Mc Daniel, S., \& Green, L. 2012).

\section{KESIMPULAN}

Berdasarkan rumusan masalah dan hipotesis yang dikemukakan serta hasil penelitian yang didasarkan pada hasil analisis data dan pembahasan, maka kesimpulan yang dapat dikemukakan adalah sebagai berikut:

1. Pembelajaran dengan model pembelajaran inkuiri terbimbing pada kelas eksperimen terlaksana dengan baik dan sesuai dengan tujuan pembelajaran. Keterlaksanaan pembelajaran dan ketepatan waktu selalu mengalami peningkatan pada setiap pertemuan.

2. Pembelajaran dengan model pembelajaran inkuiri terbimbing berpengaruh terhadap motivasi belajar siswa materi kelangkaan dan kebutuhan kelas VII SMPN 1 Sumbergempol Tulungagung tahun ajaran 2018/2019.

3. Pembelajaran dengan model pembelajaran inkuiri terbimbing juga berpengaruh terhadap hasil belajar siswa materi kelangkaan dan kebutuhan kelas VII SMPN 1 Sumbergempol Tulungagung tahun ajaran 2018/2019.

4. Pembelajaran dengan model pembelajaran inkuiri terbimbing berpengaruh signifikan terhadap motivasi dan hasil belajar siswa materi kelangkaan dan kebutuhan kelas VII SMPN 1 Sumbergempol Tulungagung tahun ajaran 2018/2019.

\section{DAFTAR PUSTAKA}

Baharuddin \& Wahyuni, E. N. (2012). Teori Belajar dan Pembelajaran. Bandung: ArRuzz Media.

Deta, U, A., Suparmi \& Widha, S. (2013). Pengaruh Metode Inkuiri Terbimbing dan Proyek, Kreativitas, serta Keterampilan Proses Sains Terhadap Prestasi Belajar Siswa. Jurnal Pendidikan Fisika Indonesia. 9 (2), 28-34.

Djamarah, S. B. (2002). Psikologi Belajar. Jakarta: Rineka Cipta

Djamarah, S. B. (2010). Strategi Belajar Mengajar. Jakarta: Rineka Cipta. Irmawati, C. (2003). Pengaruh Metode Kolaborasi. Jakarta : Penerbit Erlangga.

Mc Daniel, S., \& Green, L. (2012). Independent Interactive Inquiry-Based Learning Modules Using Audio-Visual Instruction in Statistics. Journal of Education, 6 
(1): 2-18. Diambil 10 Mei 2018, dari: http:// www. Scholarship. Org/uc/item/322385kq.

Novita, A. M., Diawati, C., \& Fadiawati, N. (2013). The Guided Discovery Learning To Improve Students Learning Motivation And Concept Masteries Of Colloid System. Jurnal Pendidikan Kimia, 1(1), 1-8.

Purwanto, A. (2012). Kemampuan Berpikir Logis SMAN 8 Kota Bengkulu dengan Menerapkan Model Inkuiri Terbimbing dalam Pembelajaran Fisika. Jurnal Exacta, 10(2), ISSN 1412-3617.

Puspita, A. T \& Jatmiko, B. (2013). Implementasi Model Pembelajaran Inkuiri Terbimbing (Guided Inquiry) Terhadap Keterampilan Berpikir Kritis Siswa pada Pembelajaran Fisika Materi Fluida Statis Kelas XI di SMA Negeri 2 Sidoarjo. Universitas Negeri Surabaya. 2(3), 122-123.

Rahmawati, R. S. (2014). Pengaruh Pembelajaran Inkuiri Terbimbing terhadap Motivasi dan Hasil Belajar Siswa Kelas XI IPA SMA Negeri 10 Malang. Skripsi, Universitas Negeri Malang, Indonesia.

Reliyana, R., Rudibyani, R. B., \& Efkar, T. (2014). Efektivitas Pembelajaran Inkuiri Terbimbing dalam Meningkatkan Motivasi Belajar dan Penguasaan Konsep Siswa. Jurnal Pendidikan Kimia, 3(2), 1-14

Sanjaya, W. (2009). Perencanaan dan Desain Sistem Pembelajaran. Jakarta: Kencana.

Sapriya. (2009). Pendidikan IPS Konsep dan Pembelajaran. Bandung: Remaja Rosdakarya.

Sudjana, N. (2002). Metode Statistika. Bandung: Tarsito.

Sudjana, N. (2011). Penilaian Hasil Proses Belajar Mengajar. Bandung: PT Remaja Rosdakarya.

Sugiono. (2007). Metode Penelitian Pendidikan Kuantitatif Kualitatif dan R\&D. Bandung: Alfabeta.

Tanzeh, A. (2011). Metode Penelitian Praktis. Yogyakarta: Teras.

Trianto. (2011). Mendesain Model Pembelajaran Inovatif-Progresif. Jakarta: Kencana

Trisnawati. (2008). Implementasi Model Arcs (Attention, Relevance, Confidence, Satisfaction) dalam Pembelajaran PAI di SMAN 1 Brebes. Skripsi. Institut Agama Islam Negeri Walisongo, Indonesia 